\title{
Dendroclimatological Analysis of Radial Growth of Old-Growth Oak (Quercus Robur L.) on the Oder River Floodbank in the City of Wroctaw, South- Western Poland
}

\section{Dendroklimatološka analiza radijalnog rasta stabala starih hrastova (Quercus robur L.) na naplavnoj obali rijeke Oder u gradu Wrocławu, u jugozapadnoj Poljskoj}

\author{
Original scientific paper • Izvorni znanstveni rad \\ Received-prispjelo: 13. 7. 2017. \\ Accepted-prihvaćeno: 23. 5. 2018. \\ UDK: $630 * 811.4 ; 674.031 .632 .26$ \\ doi:10.5552/drind.2018.1745
}

\begin{abstract}
The goal of this work was to study the temporal stability of the climate/growth relationship of 15 pedunculate oak trees in Wroctaw, SW Poland. Furthermore, pointer years were defined and the span of their meteorological conditions was assessed. The tree-ring widths were measured with an accuracy of $0.01 \mathrm{~mm}$ using LINTAB ${ }^{T M} 6$ and the TSAP-Win software. The site chronology covered 128 years from 1887 to 2014. The tree rings were on average $3.56 \mathrm{~mm}$ wide and ranged from 2.10 to $5.43 \mathrm{~mm}$. Their variation was significantly influenced by temperature and precipitation. Tree-ring widths from 1965 to 2014 were most influenced (positively) by June precipitation in the year previous to the formation of the rings. From 1915 to 1964, the tree-ring widths were most strongly and negatively influenced by November precipitation recorded in the previous year. Ten pointer years were identified, three of which were positive and seven negative. Both in the group of positive pointer years (1917, 1966 and 1982) as well negative years (1923, 1951, 1953, 1960, 1981, 1989 and 2009), we were unable to determine variation patterns of temperature and precipitation. Research on the TRW series of pedunculate oaks on flood protection embankments should be continued to better understand the effect of climate conditions on annual tree growth.
\end{abstract}

Keywords: dendrochronology, pedunculate oak, pointer years, temperature, precipitation, urban area

\footnotetext{
Authors are professor and $\mathrm{PhD}$ students at Faculty of Environmental Engineering and Geodesy, Institute of Landscape Architecture at Wrocław University of Environmental and Life Sciences, Wrocław, Poland.

Autori su profesor i doktorandice Fakulteta zaštite okoliša i geodezije, Institut za krajobraznu arhitekturu Sveučilišta bioloških znanosti i zaštite okoliša u Wrocławu, Wrocław, Poljska.
} 
SAŽETAK • Cilj rada bio je proučiti vremensku stabilnost odnosa klime i rasta 15 stabala hrasta lužnjaka u Wrocławu, u jugozapadnoj Poljskoj. Nadalje, određene su pokazne godine i procijenjen raspon meteoroloških uvjeta među njima. Širine godova mjerene su s točnošću od 0,01 mm primjenom softvera LINTAB ${ }^{T M} 6$ i TSAP-Win. Kronologija staništa obuhvatila je 128 godina, od 1887. do 2014. Godovi stabala imali su prosječnu širinu 3,56 mm, a ona se kretala u rasponu od 2,10 do 5,43 mm. Na varijacije širine godova znatno su utjecale temperature $i$ količine oborina tijekom promatranog razdoblja. Na širinu godova od 1965. do 2014. najviše su utjecale (pozitivno) oborine u lipnju u godini koja je prethodila formiranju goda. Od 1915. do 1964. na širine godova najviše su utjecale, i to negativno, oborine zabilježene u mjesecu studenome prethodne godine. Utvrđeno je deset pokaznih godina, tri pozitivne i sedam negativnih. U skupini pozitivnih godina (1917., 1966. i 1982.), kao i negativnih (1923., 1951., 1953., 1960., 1981., 1989. i 2009.), nije bilo moguće odrediti model promjene temperature i količine oborina. Radi boljeg razumijevanja učinka klimatskih uvjeta na godišnji rast stabala, potrebno je nastaviti istraživanje o nizovima širine godova stabala hrasta lužnjaka koja rastu na nasipima uz rijeku.

Ključne riječi: dendrokronologija, hrast lužnjak, pokazna godina, temperatura, količina oborina, urbana područja

\section{INTRODUCTION}

\section{UVOD}

Pedunculate oak (Quercus robur L.) is a longlived tree species of the Fagaceae family. It grows in forests throughout most of Europe except in northern areas and in areas situated around the Mediterranean and in Asia Minor (Eaton et al., 2016; Helama et al., 2016). It prospers best in moderately moist, fertile loamy soil or sandy-loamy soil (Jagodziński et al., 2016), and even tolerates periodic flooding (RasheedDepardieu et al., 2015, Stojanović et al., 2015). Studies in Poland point to a spontaneous expansion of native oaks ( $Q$. pedunculate and $Q$. sessile) to poor habitats previously dominated by artificially planted Scots pine (Gniot, 2007). The volume increment of oak stands in mixed coniferous/deciduous forests exceeds the average value in single-species stands by about $30 \%$ (Bielak et al., 2015). Young oak trees tolerate lateral shading (Seneta and Dolatowski, 2012; Annighöfer et $a l ., 2015)$ and prefer full sun in later growth phases. A delay has been shown in the increase of height in shaded oaks growing in the bottom layer of pine stands in the early stages of development - usually for about 2030 years, after which a marked rise in the growth rate occurs (Paluch, 2013). Pedunculate oak is sensitive to the late spring ground frost, which in some parts of Poland may occur as late as after the $25^{\text {th }}$ of May (Kalbarczyk, 2010b; Seneta and Dolatowski, 2012). For proper growth and development, pedunculate oak requires higher temperatures than sessile oak.

Pedunculate oaks planted in cities are most commonly placed in estates and parks, but less frequently along roads because of their slow growth and difficulties with transplantation (Ziemiańska and Suchocka, 2013). In parks, the health of this tree species is mainly impacted by three factors: distance from the city center, proximity to thoroughfares, and emissions from the combustion of fossil fuels (Krzyżaniak et al., 2013; Krutul et al., 2014). The correct primary and secondary growth of oak trees in an urban space is also influenced by underground technical installations, typology of residential architecture, salinity associated with road maintenance in winter (Čermák et al., 2013; Ziemiańska and Suchocka, 2013), as well as the altered course of meteorological conditions under the influence of the "urban heat island" in relation to non-anthropogenic ecosystems (Szymanowski and Kryza, 2012; Majewski et al., 2014; Kalbarczyk et al., 2016).

In this paper, we assessed the variability in treering widths (TRWs) in oak trees, exemplified by pedunculate oaks growing on the embankments of the Oder River in an urban setting in Wrocław, and also determined the dependence of the ring widths on air temperature and precipitation. Moreover, we identified pointer years in which most oaks developed rings clearly deviating from those from adjacent years.

\section{MATERIAL AND METHODS} 2. MATERIJAL I METODE

The studied trees grew on the flood-protection embankment of the Oder River along Osobowicka street within the north-western part of the city (latitude $51^{\circ} 08^{\prime} 53^{\prime \prime} \mathrm{N}$, longitude $16^{\circ} 58^{\prime} 57^{\prime} \mathrm{E}$, altitude $112 \mathrm{~m}$ a.s.1.), on the outskirts of Wrocław's Osobowice neighborhood (Figure 1). The levee on which the oaks grew was created in 1859 . In addition to its protective function, it was also used as a strolling area. Up until 1903, several rows of oaks had been planted on the levee, but after a flood event in 1903, the height of the bank was raised. It is still used as part of the flood-protection sys-

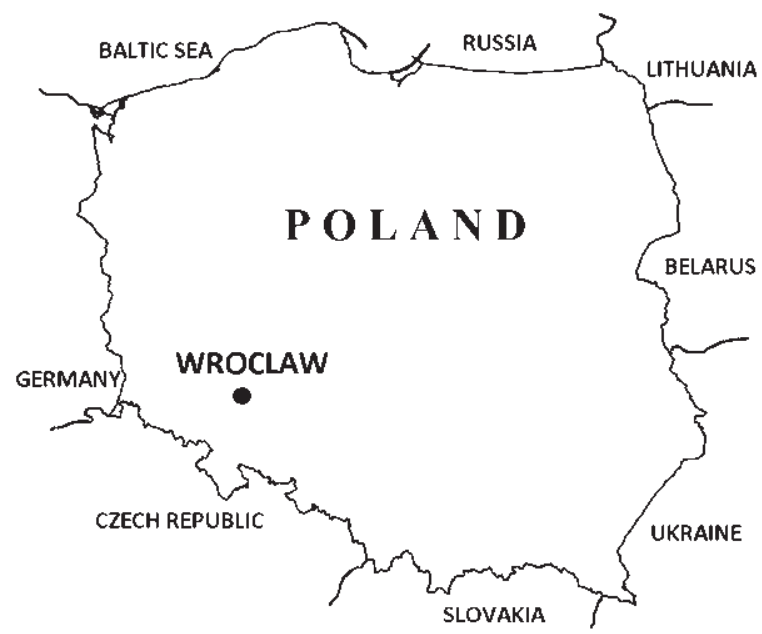

Figure 1 Location of the study site $(\bullet)$ in south-west Poland Slika 1. Lokacija mjesta istraživanja $(\bullet)$ u jugozapadnoj Poljskoj 
tem. Wrocław is located in the middle of the Silesian Lowland, with the warmest climate in Poland (Szymanowski and Kryza, 2012; Kalbarczyk, 2010a). The stem discs were collected in the summer of 2015 following a planned felling action for the modernization of the Wrocław Floodway System, implemented by the Regional Water Management Authorities.

Fifteen solitary trees at least 100 years old, denoted WO1 to WO15, were selected according to the ECO strategy described by Zielski and Krapiec (2004), which partially limits the influence of non-meteorological factors on TRWs (Bronisz et al., 2012). After drying and planing, the stem discs were used to measure ring widths along two paths, each from bark to pith, by means of LINTAB ${ }^{\mathrm{TM}} 6$ and TSAP-Win software, to an accuracy of $0.01 \mathrm{~mm}$, as was done for example by Sohar et al. (2014), Génova et al. (2015), Jansons et al. (2015), and Kalbarczyk and Ziemiańska (2016). The two tree-ring paths were cross-dated and averaged so that one tree-ring series was available for each of the 15 study trees (WO1 to WO15). One sequence out of 15 (WO12) did not meet the similarity criteria and was excluded from further analysis to avoid additional variance due to individual growth patterns.

Synchronization of TRWs against the mean for all the sequences was performed by means of COFECHA software (Holmes, 1983; Krąpiec and Szychowska-Krapiec, 2004). The similarity between the individual sequences was measured by the $t$ value - TVBT (Baillie and Pichler, 1973), TVH (Hollstein, 1980), and GLK convergence coefficient (Eckstein and Bauch, 1969). Sequences were considered similar when $t>3.5$ and $G L K>65 \%$ (Rybníček et al., 2010; Kraler et al., 2012; Sohar et al., 2012).

The quality of individual sequences was also measured by the cross-dating indicator (CDI), which included the results of both the $t$-test and the GLK (Kraler et al., 2012; Rinn, 2012). All indicators describing the quality of individual sequences were calculated using the TSAP-Win software, and confirmed the correctness of dating and their similarity. Mean TVBP and TVH for the sequences of the pedunculate oaks was 9.7 and 9.6 , respectively, while the mean GLK and CDI was $75 \%$ and $72.9 \%$, respectively.

The tree-ring sequences were described by basic statistical parameters: average TRW $(\bar{x})$, standard deviation (SD), minimums ( $\min )$ and maximums (max), and their frequency, determined on the basis of raw data, and transformed, i.e. narrower and wider growths, calculated with respect to the year preceding the formation of rings. The frequency was examined in adopted one-millimeter intervals and across three long time periods: 1887-2014, 1915-1964 and 1965-2014.

From the 14 dendrochronological sequences, we developed site chronology of pedunculate oak, denoted with the WO signature. Experience shows that chronologies composed of tree-ring series from at least 10 trees are sufficiently replicated to be used in dendroclimatological research (Matisons et al., 2013). According to professors Zielski and Krąpiec (2004), and also Mäkinen and Vanninen (1999), a sample should range from 10 to 20 trees and should be harvested in duplicate. The representativeness of the tested series was measured using the expressed population signal (EPS), a measure of the similarity between a given tree-ring chronology and a hypothetical chronology that has been infinitely replicated from the individual radii included for a specific common time interval (Wigley et al., 1984).

The site chronology (raw data, indexed, and residual chronology) was characterized, among others, by coefficients of linear trend correlation $(r t)$ and first order autocorrelation $(\mathrm{ra})$.

The effects of temperature and precipitation on the TRWs were calculated by correlation analysis, in which the dependent variable TRW was expressed in residual form, i.e. converted by procedures adopted in dendrochronology (Schweingruber, 1989; Ważny, 1990; Cedro, 2007; Stojanović et al., 2015). The analysis was conducted for a 15-month period - from June of the previous year to September of the selected year through three time periods (1887-2014, 1915-1964, and 1965-2014).

The 2015 tree-ring (the year of stem disc collection) was not included in the site chronology, because at the time of the field work the cambium activity had not finished. For the weather/TRW association, we used monthly air temperatures (temp, ${ }^{\circ} \mathrm{C}$ ) and the monthly sum of precipitation (prec, $\mathrm{mm}$ ). These values came from the recently reconstructed 217-year series of homogeneous meteorological data describing the weather conditions in urban Wrocław (Bryś and Bryś, 2010).

The span of the meteorological conditions (temperature, precipitation) in individual months was described using means from the period 1915-2014, as well as temperature and precipitation deviations in the periods 1915-1964 and 1965-2015 relative to the period 1915-2014, as well as by means of linear trend correlation coefficients.

In this study, the term 'pointer years' refers to the years during which an unidirectional change in TRW occurred in $100 \%$ of the studied tree-ring sequences (Zielski and Krąpiec, 2004; Danek et al., 2007). Positive pointer years (wide rings) and negative pointer years (narrow rings) were described by average raw data and residual chronology values, as well as average raw data TRW calculated in relation to the previous year. In addition, each designated pointer year described the temperature and precipitation during the four seasons: autumn (September to November $-9 \mathrm{p}-$ $11 \mathrm{p}$, where $\mathrm{p}$ represents the year preceding the formation of tree-rings), winter (from December to February - 12p-2), spring (from March to May - 3-5) and summer (from June to August -6-8). Air temperature was evaluated by two statistical parameters - mean $(\overline{\mathrm{x}})$ and standard deviation (SD), designated for the 1915-2014 period, and the mean in the designated pointer year $(\delta)$. A given season was considered normal (average), when the air temperature in a given pointer year met the following conditions $\bar{x}-1.0 S D \leq \delta \leq \bar{x}+1.0 S D$; warm $\bar{x}$ $+1.0 S D<\delta \leq \bar{x}+1.5 S D ; \operatorname{hot} \delta>\bar{x}+1.5 S D ; \operatorname{cool} \bar{x}-1.5$ 


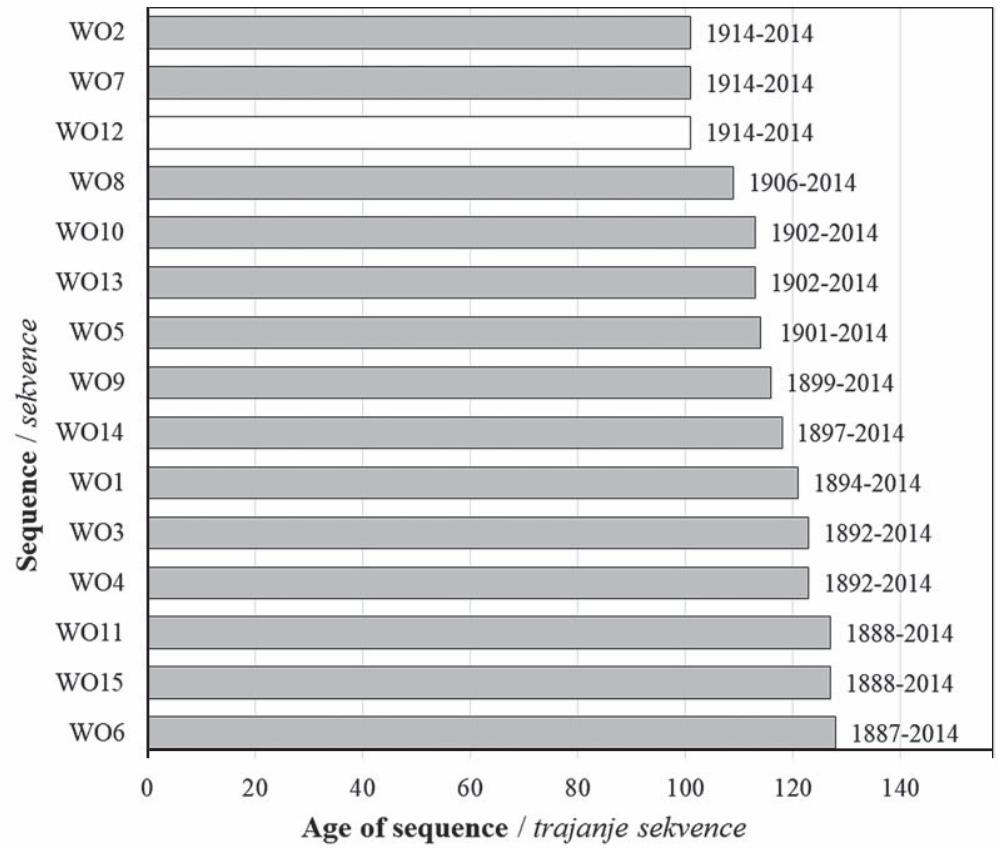

Figure 2 Dating of individual tree-ring sequences of pedunculate oaks from 1887-2014

Slika 2. Pojedinačne sekvence širine godova hrasta lužnjaka od 1887. do 2014. godine

$S D \leq \delta<\bar{x}-1.0 S D ;$ and cold $\delta<\bar{x}-1.50 S D$. A season was considered normal in terms of precipitation when, in a given pointer year, precipitation was $76 \%$ to 125 $\%$ of long-term mean; dry - from $50 \%$ to $75 \%$; very dry $<50 \%$; humid from $126 \%$ to $150 \%$; and very humid $>150 \%$ of the long-term precipitation mean.

\section{RESULTS}

\section{REZULTATI}

\subsection{Individual tree-ring width series}

\subsection{Pojedinačni nizovi širina godova}

The average number of years of all the analyzed individual sequences ( $N$ sy) of pedunculate oak was 116 years and ranged from 101 years (1914-2014) in the case of trees marked with signatures WO2, WO7, and WO12, to 128 years in the case of the tree WO6 that grew from 1887-2014 (Figure 2). Six of the fifteen considered sequences were over 120 years. One sequence designated by the WO12 code, due to a low similarity to others $(t<3.5, G L K<65 \%)$, was excluded from further analysis.

The highest average TRW was designated for trees $\operatorname{WO} 8(\bar{x}=4.83 \mathrm{~mm}, N$ sy $=109$ years $)$ and WO2 $(\bar{x}=4.79 \mathrm{~mm}, N$ sy $=101$ years) (Figure 3$)$. These trees (WO8 and WO2) also had the widest tree-rings, 11.30 $\mathrm{mm}$ and $11.71 \mathrm{~mm}$, respectively. The lowest average TRW was measured for trees WO6 $(\bar{x}=2.19 \mathrm{~mm}, N$ sy $=128$ years $)$, and $\mathrm{WO} 9(\bar{x}=2.82 \mathrm{~mm}, N$ sy $=116$ years $)$.

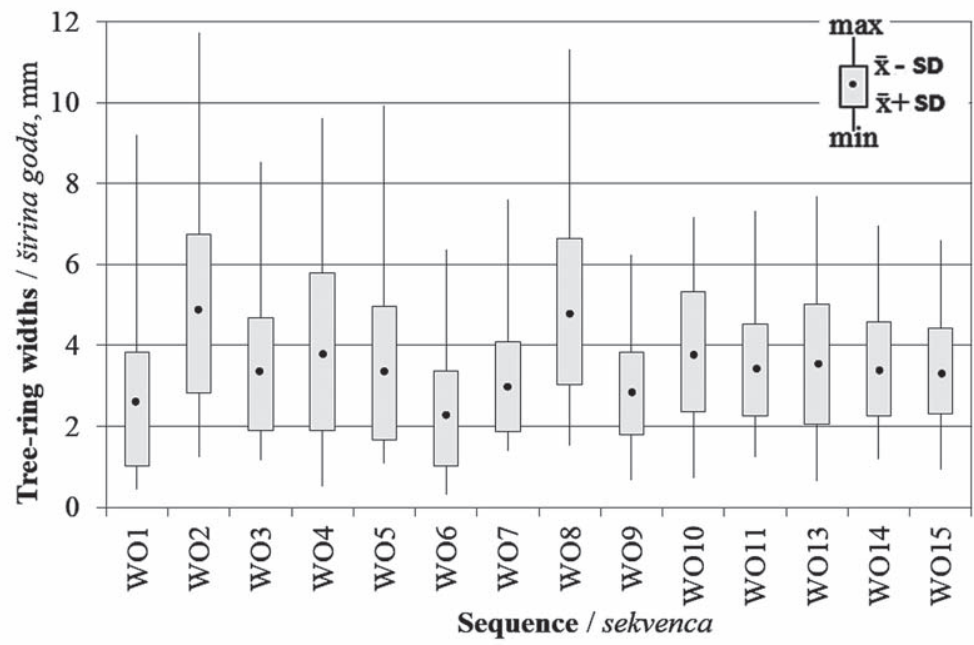

Figure 3 Statistical characteristics of individual sequences describing the variations of tree-ring width of pedunculate oak from 1887-2014. Symbols as in Table 1

Slika 3. Statistička obilježja pojedinačnih sekvenci koje opisuju varijacije širine godova stabala hrasta lužnjaka od 1887. do 2014. godine (značenje oznaka dano je uz tablicu 1.) 


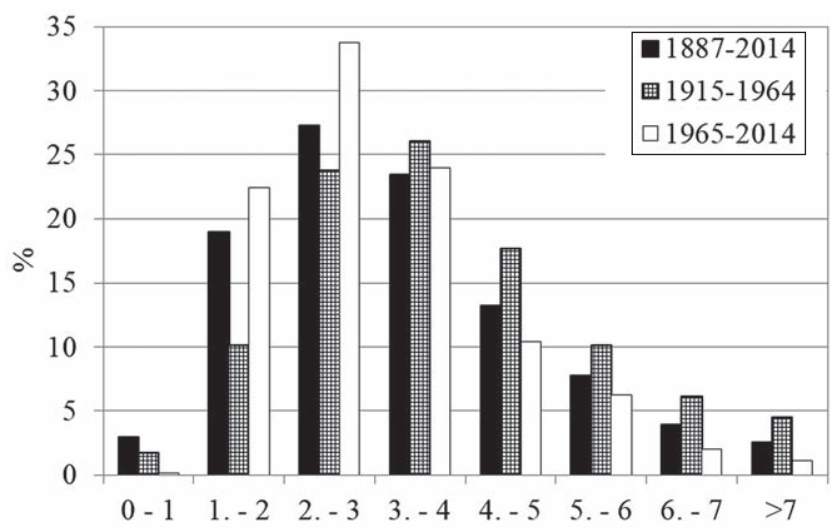

a)

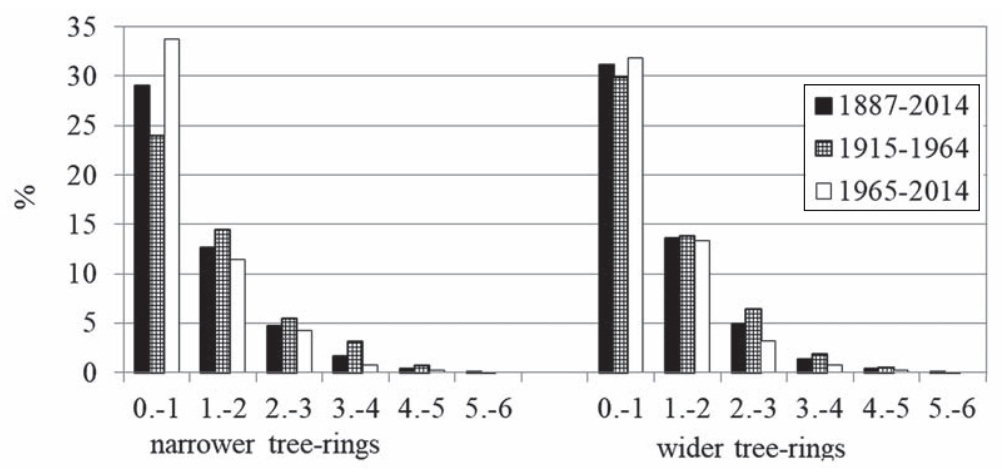

b)

Figure 4 Frequency (\%) of TRWs in individual sequences of pedunculate oaks in one-millimeter intervals. a) actual ring size, b) size of the rings in relation to the previous year.

Slika 4. Frekvencija (\%) širina godova u pojedinim sekvencama hrasta lužnjaka u intervalima od jednog milimetra: a) stvarna širina goda, b) širina goda s obzirom na prethodnu godinu

The minimum sizes of TRWs in the individual trees ranged from $0.34 \mathrm{~mm}$ in WO6 (Nsy $=128$ years) to $1.53 \mathrm{~mm}$ in WO8 (Nsy $=109$ years). The standard deviation in assessing the variability of TRWs in the analyzed individual sequences ranged from $1.01 \mathrm{~mm}$ in WO9 $(N$ sy $=116$ years) to $1.95 \mathrm{~mm}$ in WO2 (Nsy $=$ 101 years) and WO4 (Nsy $=123$ years).

In the period $1887-2014$, the most common pedunculate oak TRW was 2 to $3 \mathrm{~mm}(27.3 \%$ of all measured rings), followed by 3 to $4 \mathrm{~mm}(23.4 \%)$ and 1 to $2 \mathrm{~mm}(19 \%)$. Only $2.4 \%$ of all measured TRWs were greater than $7 \mathrm{~mm}$ (Figure 4a).

The frequency distribution of individual TRW sequences differed between the two half century periods 1915-1964 and 1965-2014 from the period 1887-2014. TRWs from 3 to $4 \mathrm{~mm}$ and $>7 \mathrm{~mm}$ were most common in the earlier 1915-1964 period (26\%), and 2-3 mm TRWs in the later 1965-2014 period (about $34 \%$ ).

Frequency analysis, showing TRWs in relation to the preceding year, indicated that most often (in approx. $30 \%$ of cases) the year-to-year difference did not exceed $1 \mathrm{~mm}$ (Figure 4b). The negative difference in TRW was about $10 \%$ more frequent in the second 50 year period (1965-2014). A year-to-year difference for the remaining TRW intervals, i.e. 1-2, 2-3, 3-4, 4-5 and 5-6 (both positive and negative), was observed more frequently in the earlier 50-year period (1915-1964).

\subsection{Site chronology}

3.2. Kronologija staništa

The course of the considered dendrochronological curves of individual pedunculate oak sequences, along with the determined site chronology, is shown in Figure 5. In the period 1915-2014, which covers all the study samples, the average raw data TRW of pedunculate oak site chronology was $3.56 \mathrm{~mm}$. In the earlier part of that period (1915-1964), the average was higher, at $3.96 \mathrm{~mm}$ (Table 1 and Figure 5). The standard deviation (SD) of TRW from 1915-2014 was $0.87 \mathrm{~mm}$, wherein SD in the earlier half of that period was higher at $0.90 \mathrm{~mm}$ and was $0.26 \mathrm{~mm}$ more than in the later half of that period. TRW in the site chronology ranged from 0.20 to $5.43 \mathrm{~mm}$. A higher difference between maximum and minimum TRW (3.02 $\mathrm{mm})$ was found in the earlier half of that period (1915-1964).

The researched 100-year period of pedunculate oak chronology is characterized by a negative trend ( $r t$ $=-0.44, \alpha<0.01$ ), which shows the presence of an age related trend. The smaller year-to-year TRWs were statistically proven $(r t=-0.24, \alpha<0.1)$ in the later half of the analyzed long-term period (1965-2014). The I ${ }^{\circ}$ autocorrelation coefficient was clearly visible during the 1915-2014 period ( $r a=0.38, \alpha<0.01$ ), and slightly lower from 1915-1964 $(r a=0.22, \alpha<0.1)$. After the transformation of raw data TRW data into residual, we 
Table 1 Statistical indicators describing chronology in various long-term periods

Tablica 1. Statistički pokazatelji koji opisuju kronologiju u različitim dugoročnim razdobljima

\begin{tabular}{|c|c|c|c|c|}
\hline \multirow{2}{*}{$\begin{array}{l}\text { Indicator } \\
\text { Pokazatelj }\end{array}$} & \multirow{2}{*}{$\begin{array}{c}\text { Period } \\
\text { Razdoblje }\end{array}$} & \multicolumn{3}{|c|}{ Chronology / Kronologija } \\
\hline & & $\begin{array}{c}\text { Raw-data } \\
\text { Neobrađeni podatci }\end{array}$ & $\begin{array}{c}\text { Indexed } \\
\text { Indeksirani podatci }\end{array}$ & $\begin{array}{c}\text { Residual } \\
\text { Ostatak }\end{array}$ \\
\hline \multirow{3}{*}{$\begin{array}{l}\bar{x} \pm S D \\
(\mathrm{~mm})\end{array}$} & 1 & $3.56 \pm 0.87$ & $0.99 \pm 0.21$ & $0.73 \pm 0.25$ \\
\hline & 2 & $3.96 \pm 0.90$ & $1.02 \pm 0.23$ & $0.74 \pm 0.29$ \\
\hline & 3 & $3.16 \pm 0.64$ & $0.97 \pm 0.19$ & $0.72 \pm 0.21$ \\
\hline \multirow{3}{*}{$\begin{array}{c}\min \\
(\mathrm{mm})\end{array}$} & 1 & 2.10 & 0.59 & 0.09 \\
\hline & 2 & 2.41 & 0.59 & 0.09 \\
\hline & 3 & 2.10 & 0.63 & 0.24 \\
\hline \multirow{3}{*}{$\begin{array}{l}\max \\
(\mathrm{mm})\end{array}$} & 1 & 5.43 & 1.48 & 1.43 \\
\hline & 2 & 5.43 & 1.48 & 1.43 \\
\hline & 3 & 4.45 & 1.46 & 1.22 \\
\hline \multirow{3}{*}{$r t$} & 1 & -0.441 & $-0.01^{\mathrm{ns}}$ & $-0.01^{\mathrm{ns}}$ \\
\hline & 2 & $0.01^{\mathrm{ns}}$ & $0.22^{\mathrm{ns}}$ & $-0.16^{\mathrm{ns}}$ \\
\hline & 3 & -0.243 & $0.07^{\mathrm{ns}}$ & $0.02^{\mathrm{ns}}$ \\
\hline \multirow{3}{*}{$r a$} & 1 & $0.38^{1}$ & 0.212 & $-0.05^{\text {ns }}$ \\
\hline & 2 & 0.223 & 0.243 & $0.07^{\mathrm{ns}}$ \\
\hline & 3 & $0.19^{\text {ns }}$ & $0.10^{\mathrm{ns}}$ & $-0.12^{\mathrm{ns}}$ \\
\hline
\end{tabular}

Explanation: $\bar{x}$ - average / prosječna vrijednost, $S D$ - standard deviation / standardna devijacija, min - lowest value / najniža vrijednost, max - highest value / najviša vrijednost, rt - linear trend correlation coefficient / koeficijent korelacije linearnog trenda, $r a-\mathrm{I}^{\circ}$ autocorrelation coefficient, long-term period / koeficijent autokorelacije, dugoročno razdoblje: 1 - 1915 - 2014, $2-1915-1964,3-1965-2014,{ }^{1} \alpha \leq 0.01,{ }^{2} \alpha \leq 0.05,{ }^{3} \alpha \leq 0.1$, ns - not statistically significant at least at $\alpha \leq 0.1 /$ nije statistički značajno pri $\alpha \leq 0,1$

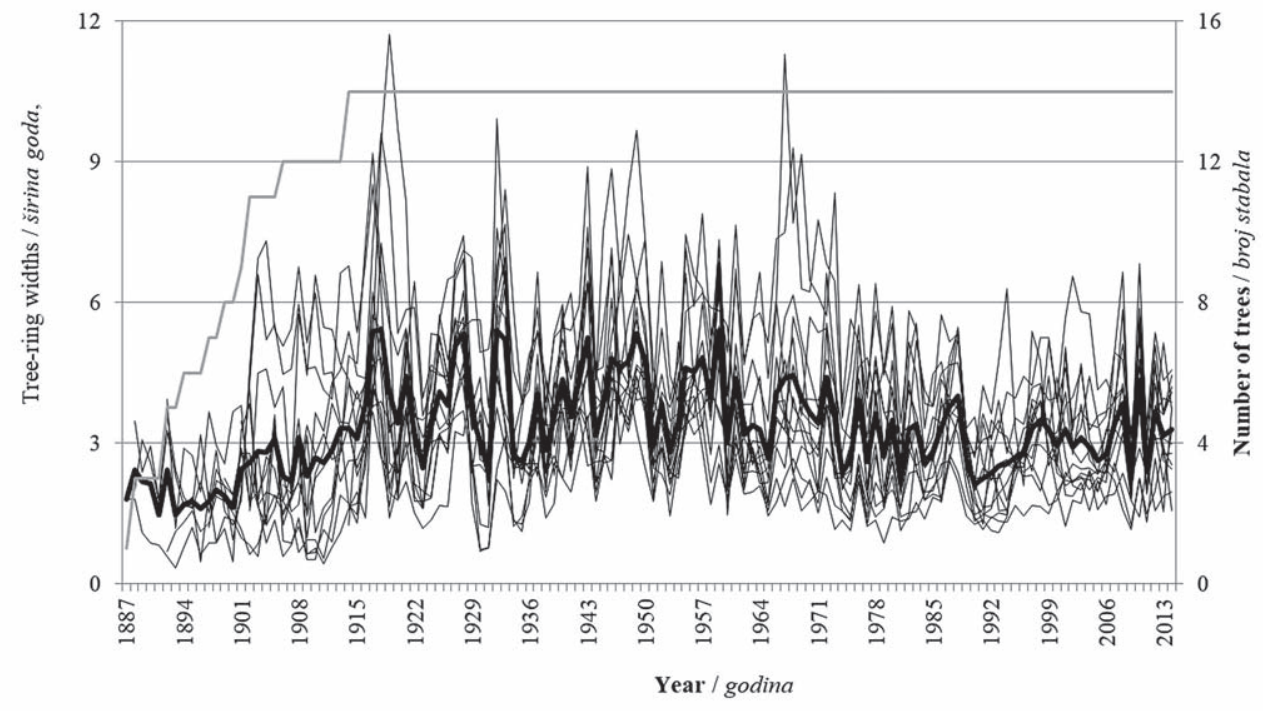

Figure 5 Dendrochronological curves of individual sequences of pedunculate oak comprising the WO site chronology $(\square)$ from 1887-2014 against the background of the size of the research sample (number of trees) in subsequent years in the considered long-term period 1915-2014

Slika 5. Dendrokronološke krivulje pojedinih sekvenci hrasta lužnjaka koje obuhvaćaju kronologiju WO mjesta ( $)$ od 1887. do 2014. u odnosu prema veličini istraživačkog uzorka (broj stabala) u kasnijim godinama razmatranoga dugoročnog razdoblja od 1915. do 2014.

managed to eliminate both the age-related trend and the impact of the growth from the preceding year in the 3 considered long-term periods.

\subsection{Temperature and precipitation, and site} chronology relations

3.3. Temperatura i oborine te odnosi među kronologijama staništa

Correlation analysis was carried out for the three periods of research (1915-2014, 1915-1964, 19652014) between TRW and air temperature (temp), and precipitation (prec) and indicated that each of the examined meteorological elements interacted with different strengths and directions - positive or negative (Figure 6ab). The strongest positive impact of temp on TRW, in all studied periods, was evident in December of the year preceding the tree-ring formation. In the first half of the full long-term period study, i.e. from 1915-2014, the air temperature of the year preceding the formation of the tree-ring - from July to October, as well as the observed year - from January to March and 


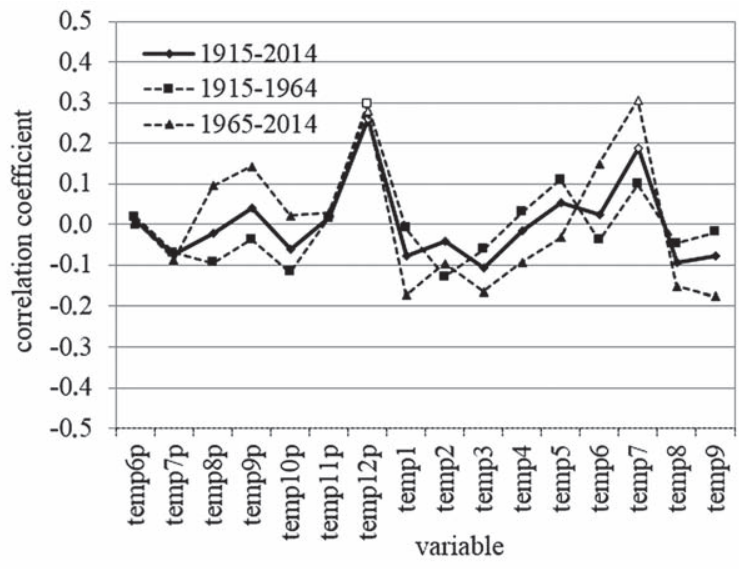

a)

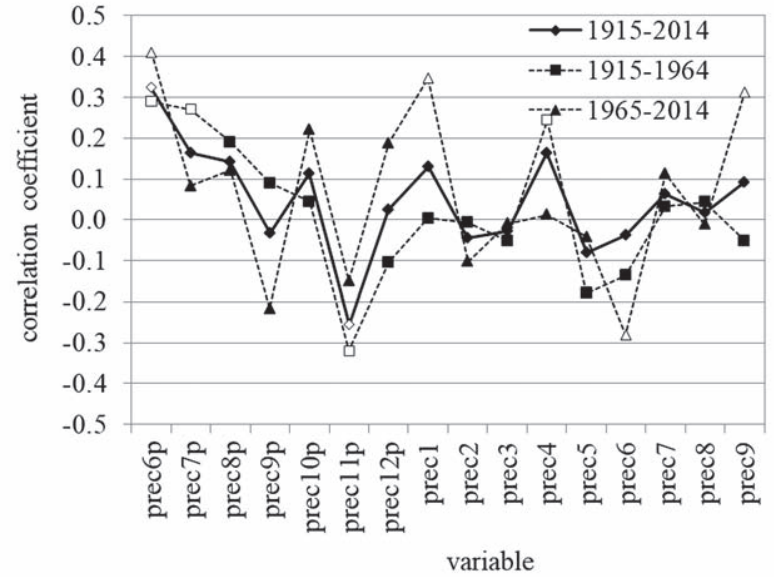

b)

Figure 6 Effect of air temperature (a) and precipitation (b), from June of the year preceding the formation of rings (temp6p, prec6p) till September of the current year (temp9, prec9), on the size of annual tree-rings of pedunculate oak in various long-term periods $(\mathrm{p}$ - year preceding the formation of annual growth, temp - air temperature, prec - precipitation, $1,2 \ldots \ldots$ 12 - consecutive month of the year, marker with no fill - relationship significant at $\alpha \leq 0.1$ )

Slika 6. Utjecaj temperature zraka (a) i oborina (b) od lipnja godine prije nastanka goda (temp6p, prec6p) do rujna tekuće godine (temp9, pre-9) na širinu goda hrasta lužnjaka u tekućoj godini za različita dugoročna razdoblja ( $\mathrm{p}$ - godina koja prethodi formiranju godišnjeg rasta, temp - temperatura zraka, prec - oborine, 1, $2 \ldots 12$ - uzastopni mjesec u godini, prazne oznake - korelacija je značajna pri $\alpha \leq 0,1)$

in June, and from August to September, contributed to a reduction of TRW in the pedunculate oaks.

In the second half of the studied long-term period from 1965-2014, the effect on TRW was slightly different. TRW was favorably influenced by air temperature in the previous year from August to October as well as in the observed year in June, and differently, negatively, in the current year - from April to May. In all three studied long-term periods, TRW correlated positively with precipitation in the previous year from June to August and October, and the current year in January, April and July, while negatively with precipitation in the previous year in November, as well as in the current year in February, March, May and June. The strongest positive impact of precipitation on TRW was evident for June precipitation in the year preceding the formation of the tree-rings ( $r$ varied from 0.29 in 1915-1964 to 0.41 in 1965-2014) and in January $(r=0.35, \alpha \leq 0.01)$ and in September $(r=$ $0.31, \alpha \leq 0.01)$ in the current year, but only from 1965-2014. TRW was significantly negatively influenced by precipitation in November in the preceding year, especially from $1915-1964(r=-0.32, \alpha \leq 0.01)$ and in June in the current year $(r=-0.28, \alpha \leq 0.01)$, but only from 1965-2014.

\subsection{Variability of meteorological conditions 3.4. Varijabilnost meteoroloških uvjeta}

In the period $1915-2014$, the air temperatures ranged, on average, from $-1.4{ }^{\circ} \mathrm{C}$ in January to $19.3^{\circ} \mathrm{C}$ in July (Figure 7a). The average annual air temperature in the earlier 50 -year period (1915-1964) was $8.9^{\circ} \mathrm{C}$, $0.3{ }^{\circ} \mathrm{C}$ less than for the whole long-term period $(1915$ 2014). This was determined by lower air temperatures recorded in winter, especially in January $\left(0.4{ }^{\circ} \mathrm{C}\right.$ lower in comparison to the 1915-2014 period) and in February $\left(0.7^{\circ} \mathrm{C}\right.$ lower in comparison to the $1915-2014$ pe- riod), and early spring, i.e. in March $\left(0.5^{\circ} \mathrm{C}\right.$ lower in comparison to the $1915-2014$ period). On the other hand, in the second half of the long-term period, the average air temperature was higher than the norm (1915-2014) in nearly all months of the year.

The largest temperature deviations, ranging from $0.2^{\circ} \mathrm{C}$ to $0.7^{\circ} \mathrm{C}$, in the $1965-2014$ period compared to the 1915-2014 period were evident from January to March, and in August and December. A positive indicator trend in the two 50-year periods calculated in relation to the 1915-2014 long-term period confirms the correlation analysis of the significance of the linear trend of monthly temperature values (Table 2).

A significant positive air temperature trend was evident in several months from 1915-2014. The value of the correlation coefficient for significant relationships between air temperature and TRW ranged from 0.17 for air temperature in June and November in the year preceding the forming of the tree-rings, to 0.32 in August of the current year. At the same time, the significant increase in air temperature from April to August throughout the long-term period was primarily determined by above-average temperature values in the later half of the long-term period (1965-2014). The average annual amount of precipitation during the whole research period was $578 \mathrm{~mm}$ (Figure 7b). Precipitation in the two analyzed 50-year periods differed by only $6 \mathrm{~mm}$. A slightly higher precipitation was recorded in the later 50 year period (1965-2014, generally from May to July). The biggest differences in total precipitation between the earlier and later halves of the considered period (1915-2014) were reported in July (almost $10 \mathrm{~mm}$ ), being wetter in the later half. In contrast to air temperature, precipitation was marked by a mostly negative trend, e.g. in January from 1915-1964 $(r=-0.47, \alpha \leq 0.01)$ and in April from 1915-2014 $(r=$ $-0.23, \alpha \leq 0.05)$. 


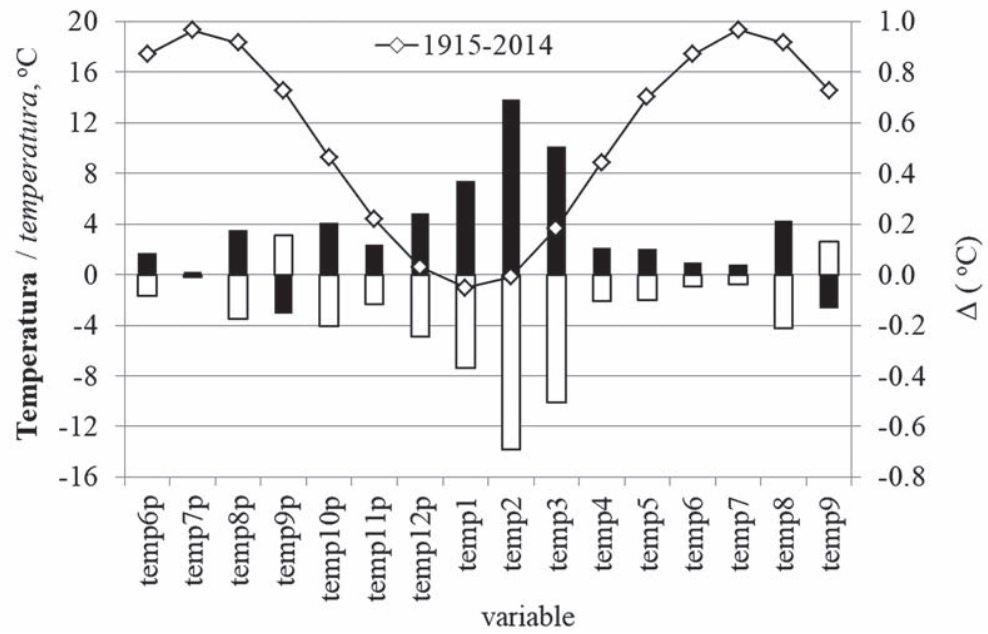

a)

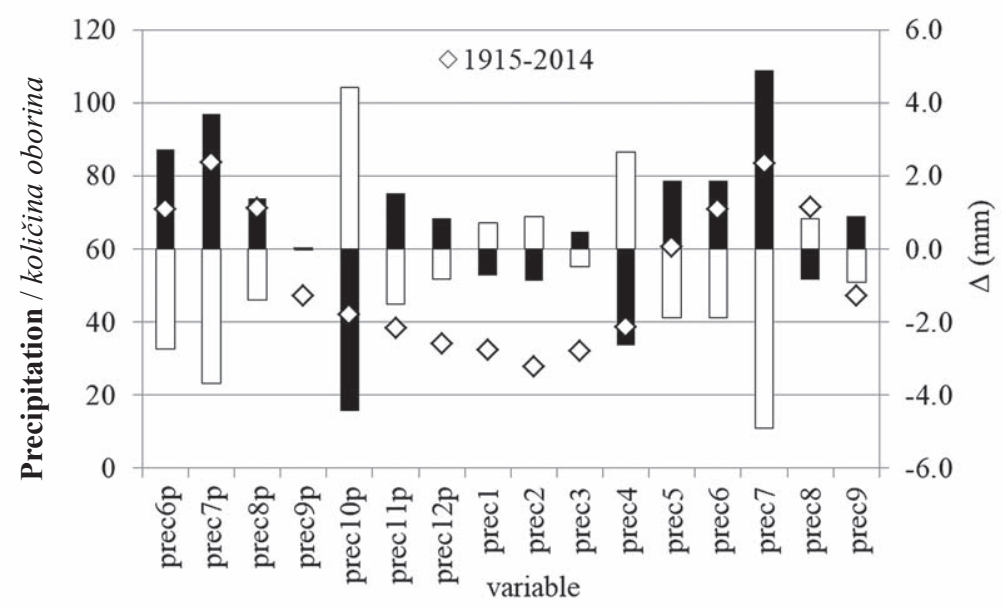

b)

Figure 7 Air temperature (a) and precipitation variation (b) as well as their monthly deviations in 1915-1964 (ם) and 1965-2014 (घ) in relation to the 1915-2014 period. Explanation as in Figure 6.

Slika 7. Promjene temperature zraka (a) i količine oborina (b) te njihova mjesečna odstupanja u razdoblju 1915. - 1964. (口) i 1965. - 2014. (ロ) u odnosu prema razdoblju 1915. - 2014.

Table 2 Temperature and precipitation linear trend in consecutive analyzed months Tablica 2. Linearni trend temperature i oborina u uzastopnim analiziranim mjesecima

\begin{tabular}{|c|c|c|c|c|c|c|c|}
\hline \multirow{2}{*}{\multicolumn{2}{|c|}{$\begin{array}{l}\text { Month } \\
\text { Mjesec }\end{array}$}} & \multicolumn{2}{|c|}{$1915-2014$} & \multicolumn{2}{|c|}{ 1915-1964 } & \multicolumn{2}{|c|}{$1965-2015$} \\
\hline & & \multirow{2}{*}{$\begin{array}{c}\begin{array}{c}\text { temp } \\
\text { o } \mathrm{C}\end{array} \\
0.17^{3}\end{array}$} & \multirow[t]{2}{*}{$\begin{array}{c}\text { prec } \\
\mathrm{mm}\end{array}$} & \multirow{2}{*}{ 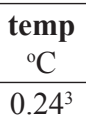 } & \multirow[t]{2}{*}{$\begin{array}{c}\text { prec } \\
\mathrm{mm}\end{array}$} & \multirow[t]{2}{*}{$\begin{array}{c}\text { temp } \\
{ }^{\circ} \mathrm{C} \\
\end{array}$} & \multirow[t]{2}{*}{$\begin{array}{c}\text { prec } \\
\mathrm{mm}\end{array}$} \\
\hline \multirow{7}{*}{$\begin{array}{c}\text { previous year } \\
\text { prethodna godina }\end{array}$} & 6 & & & & & & \\
\hline & 7 & & & & & $0.40^{1}$ & \\
\hline & 8 & $0.30^{1}$ & & & & $0.57^{1}$ & \\
\hline & 9 & & & & & & \\
\hline & 10 & & $-0.23^{2}$ & & $-0.24^{3}$ & & \\
\hline & 11 & $0.17^{3}$ & & $0.25^{3}$ & & & $-0.28^{2}$ \\
\hline & 12 & & & & & & \\
\hline \multirow{9}{*}{$\begin{array}{l}\text { current year } \\
\text { tekuća godina }\end{array}$} & 1 & & & $-0.26^{3}$ & $-0.47^{1}$ & & \\
\hline & 2 & & & & & & \\
\hline & 3 & & & & & & $0.24^{3}$ \\
\hline & 4 & $0.19^{3}$ & $-0.23^{2}$ & & & $0.59^{1}$ & \\
\hline & 5 & & & & & $0.38^{1}$ & \\
\hline & 6 & & & & & $0.27^{3}$ & \\
\hline & 7 & $0.18^{3}$ & & $0.27^{3}$ & & $0.46^{1}$ & \\
\hline & 8 & $0.32^{1}$ & & & & $0.52^{1}$ & \\
\hline & 9 & & & & & & \\
\hline
\end{tabular}

Explanation: temp - air temperature / temperature zraka; prec - precipitation / količina oborina $;{ }^{1} \alpha \leq 0.01 ;{ }^{2} \alpha \leq 0.05 ;{ }^{3} \alpha \leq 0.1$; $1,2 \ldots \ldots 12$ - months of the year / mjeseci u godini 


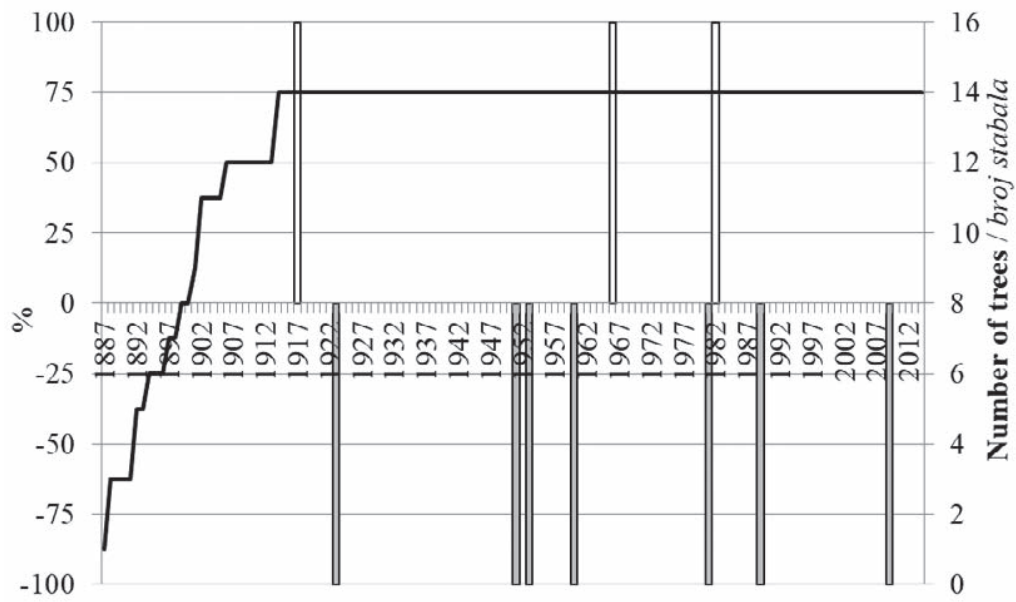

Figure 8 Distribution of identified positive and negative pointer years of pedunculate oak in the 1915-2014 long-term period and the size of the research sample (number of trees) in the respective years of the considered long-term period (一)

Slika 8. Raspodjela identificiranih pozitivnih i negativnih pokaznih godina hrasta lužnjaka u dugoročnom razdoblju 1915. 2014. i veličine istraživačkih uzoraka (broj stabala) u pojedinim godinama razmatranoga dugoročnog razdoblja (一)

Table 3 Characteristics of pointer years of pedunculate oak and assessment of temperature and precipitation in further seasons

Tablica 3. Obilježja pokaznih godina hrasta lužnjaka i procjena temperature i količine oborina u sljedećim godišnjim dobima

\begin{tabular}{|c|c|c|c|c|c|c|c|c|c|c|c|c|}
\hline \multirow{4}{*}{$\begin{array}{l}\text { Pointer } \\
\text { years } \\
\text { Pokazne } \\
\text { godine }\end{array}$} & \multirow{4}{*}{$\begin{array}{l}\text { Type of pointer } \\
\text { year } \\
\text { Obilježje pokazne } \\
\text { godine }\end{array}$} & \multirow{2}{*}{\multicolumn{2}{|c|}{$\begin{array}{c}\text { Chronology value } \\
\text { Kronološka vrijednost } \\
\mathrm{mm}\end{array}$}} & \multirow{4}{*}{$\begin{array}{c}\text { Measured average } \\
\text { tree-ring width relative } \\
\text { to the previous year } \\
\text { Prosječna vrijednost } \\
\text { izmjerenih širina godova u } \\
\text { odnosu prema prethodnoj } \\
\text { godini }\end{array}$} & \multicolumn{8}{|c|}{ Conditions / Uvjeti } \\
\hline & & & & & \multirow{2}{*}{\multicolumn{4}{|c|}{$\begin{array}{l}\text { thermal } \\
\text { temperatura } \\
\text { (temp, }{ }^{\circ} \mathrm{C} \text { ) }\end{array}$}} & \multirow{2}{*}{\multicolumn{4}{|c|}{$\begin{array}{l}\text { precipitation } \\
\text { količina oborinc } \\
\quad \text { (prec, } \mathrm{mm})\end{array}$}} \\
\hline & & \multirow{2}{*}{$\begin{array}{l}\text { raw-data } \\
\text { neobrađeni } \\
\text { podatci }\end{array}$} & \multirow{2}{*}{$\begin{array}{c}\text { residual } \\
\text { ostatak }\end{array}$} & & & & & & & & & \\
\hline & & & & & A & W & $\mathrm{Sp}$ & $\mathrm{S}$ & A & $\mathrm{W}$ & $\mathrm{Sp}$ & $\mathrm{S}$ \\
\hline 1917 & positive & 5.39 & 1.16 & 1.56 & & & & & & & & \\
\hline 1923 & negative & 2.46 & 0.42 & -0.76 & & & & & & & & \\
\hline 1951 & negative & 2.96 & 0.19 & -1.79 & & & & & & & & \\
\hline 1953 & negative & 2.80 & 0.53 & -1.04 & & & & & & & & \\
\hline 1960 & negative & 3.01 & 0.21 & -2.38 & & & & & & & & \\
\hline 1966 & positive & 4.06 & 1.04 & 1.39 & & & & & & & & \\
\hline 1981 & negative & 2.12 & 0.40 & -1.36 & & & & & & & & \\
\hline 1982 & positive & 3.29 & 0.92 & 1.17 & & & & & & & & \\
\hline 1989 & negative & 2.67 & 0.34 & -1.32 & & & & & & & & \\
\hline 2009 & negative & 2.24 & 0.24 & -1.62 & & & & & & & & \\
\hline
\end{tabular}

Explanation: A - autumn (season from September to November, taking place in the year previous to the formation of tree-rings), W - winter (season from December of the year preceding the formation of tree-rings to February of the current year), Sp - spring (season from March till May), S - summer (season from June till August)

Objašnjenje: $A$ - jesen (sezona od rujna do studenoga; odnosi se na godinu koja je prethodila formiranju stabla), $W$ - zima (sezona od prosinca godine koja prethodi formiranju stabla do veljače tekuće godine), Sp - proljeće (sezona od ožujka do svibnja), S - ljeto (sezona od lipnja do kolovoza)

\subsection{Pointer years}

\subsection{Pokazne godine}

We distinguished 10 pointer years in the 100 year long-term period, identified by pedunculate oak TRW. Seven were negative and three positive (Figure 8). The 3 positive pointer years were 1917, 1966 and 1982, and the 7 negative years were 1923, 1951, 1953, 1960, 1981, 1989 and 2009. The greatest annual growth occurred in 1917 at $5.39 \mathrm{~mm}$, and the smallest in 1981 at $2.12 \mathrm{~mm}$ (Table 3, Table 4).

In positive pointer years, TRW in residual form ranged from 0.92 to $1.16 \mathrm{~mm}$, and average raw-data TRW in relation to the previous year ranged from 1.17 $\mathrm{mm}$ in 1982 to $1.56 \mathrm{~mm}$ in 1917. In the year in which the widest tree-ring of the pedunculate oak developed, air temperatures were normal in the period from Sep-
Table 4 Explanation of marks in Table 3

Tablica 4. Objašnjenje oznaka u tablici 3.

\begin{tabular}{|c|l|l|}
\hline $\begin{array}{c}\text { Condi- } \\
\text { tions } \\
\text { Uvjeti }\end{array}$ & $\begin{array}{c}\text { Temperatura zraka } \\
\text { (temp, }{ }^{\circ} \mathrm{C} \text { ) }\end{array}$ & $\begin{array}{c}\text { Thermal } \\
\text { Toličina oborina } \\
\text { (prec, mm) }\end{array}$ \\
\cline { 2 - 3 } & \multicolumn{2}{|c|}{ season / godišnje doba } \\
\hline & hot / vruće & very dry / vrlo suho \\
\hline & warm / toplo & dry / suho \\
\hline & normal / normalno & normal / normalno \\
\hline & cool / hladno & humid / vlažno \\
\hline & cold / vrlo hladno & very humid / vrlo vlažno \\
\hline
\end{tabular}

tember of the year preceding the formation of the rings to February of the current year, i.e. autumn and winter. The following season, spring (March-May) was cold, and the summer (June-August) was warm. Precipita- 
tion in 1917 also varied significantly: autumn and summer - dry, spring - wet, and winter - average (normal). Two subsequent positive pointer years were also characterized by an individual pattern of temperature and precipitation. In 1966, autumn was cold and dry, winter - average (normal) and humid, and spring and summer did not deviate from the norm in terms of both these categories. There was another distribution of temperature and precipitation in 1982, where the autumn was average and humid, winter and spring average in terms of variations of temperature and precipitation, and summer warm and dry. In the group of negative pointer years, we were also unable to determine typical weather patterns, this time favorable to the formation of narrow TRW. For example, in 1923 and 1953, in which the average TRWs were only $2.46 \mathrm{~mm}$ and $2.80 \mathrm{~mm}$, autumn was cold and damp, and spring and summer - average or cool and dry. By contrast, 1981 and 2009 were dry in autumn and cool in the summer, but with normal temperatures in autumn, winter and summer.

\section{DISCUSSION}

\section{RASPRAVA}

Slightly different statistical characteristics compared to the results obtained in Wrocław for the constructed TRW chronology of pedunculate oak were obtained by Rybníček et al. (2016) in Liteň Obora (about $10 \mathrm{~km}$ from Prague), as well as Čufar et al. (2014) in Croatia. Indicators calculated for both Czech and Croatian chronologies differed from those for Wrocław, e.g. $\bar{x}$ and $S D$ were on average 1.55 and $0.16 \mathrm{~mm}$ lower, while the $\mathrm{I}^{\mathrm{o}}$ autocorrelation coefficient was higher, on average by 0.29 . The larger TRWs of pedunculate oak in Wrocław were most likely the result of the trees growing in urban conditions and not in semi-natural plant groups. In this way, the studied trees lacked neighboring tree interactions and also had greater access to solar radiation. The site from which the samples were taken, i.e. the Oder flood protection embankments, is not without significance. Even with long-lasting droughts, the root systems of the studied trees could always draw from ground water resources (in principle without limit). Besides that, Wrocław has milder winters than other Polish regions (Lorenc, 2005).

The significant positive relationship between TRW and temperature in the December of the previous year proven in this study, partially confirms the research carried out in northern Poland by Pritzkow et al. (2016), where they proved a positive correlation between the indicator describing the average surface area of vessel in the early wood of pedunculate oak and the minimum air temperature in the period 1951-2010 between the 29th of November and the 20th of January. According to Pritzkow et al. (2016), during the low temperatures in winter, damage may be caused to the tree root system, which often leads to the emergence of smaller vessels in the early wood and thus narrower TRW. Negative winter air temperatures adversely affect the cambium area and often cause variations in the development of spring wood (Khasanov, 2013). The percentage of winter damage to the tree-rings depends on the age of the tree, and decreases from approx. $76 \%$ in young specimens ( $>41$ years during harsh winters) to approx. less than $4 \%$ in older trees ( $>81$ years). According to Tulik (2014), the formation of narrow TRW and small diameter vessels in the early wood increases the susceptibility to degradation. The reduced diameter of the vessels negatively affects the hydraulic conductivity of oak tree trunks, resulting in deteriorated water transport. Matisons et al. (2013) obtained other results based on TRW, calculated only for the pointer years in Latvia and temperature and precipitation. In western Latvia, the strongest positive impact on TRW was from temperature in March and June, which is different than in Wrocław, where TRW was significantly positively influenced by temperature in July. On the other hand, in eastern Latvia, temp in December of the preceding year had a strong negative influence, similar to our study. In southeastern Estonia, from 1945-2008, pedunculate oak TRW depended significantly and favorably on temp in July (Sohar et al., 2014), i.e. the same as in the Wrocław chronology from 1965-2014. Research aimed to establish a relationship between annual pedunculate oak tree growth and temperature, precipitation and other agrometeorological elements was also carried out by (among others): Helama et al. (2016) and González-González et al. (2015), who, in their analyses, considered both early as well as late wood separately. Such research was also carried out by Bronisz et al. (2012), Čufar et al. (2014), Cedro and Nowaka (2015), Rybníček et al. (2016) and Tulik and Bijak (2016). According to Cedro and Nowak (2015) TRW variability in north-western Poland can be explained by temperature and precipitation variability even in approx. $54 \%$ of cases. According to Hughes (2002), the weather/TRW relations are stronger, the closer the studied trees grow to the natural range of the species.

In determining the pointer years, various values of unidirectional changes in tree-ring sequences are accepted, usually from $70 \%$ to $90 \%$ (Bronisz et al., 2012; Okoński et al., 2014). Due to the small sample in this study, pointer years were determined in the case of unidirectional change occurrences in tree-rings in $100 \%$ of the studied sequences. Sohar et al. (2014) determined 38 pointer years throughout Estonia from 1769-2008, including 19 positive and 19 negative, which means that wide or narrow tree-rings of pedunculate oak formed every 6-7 years. In the Wrocław chronology, pointer years were noted every 10 years, and only three of them (1923, 1966, and 1981) coincided with the pointer years designated by Sohar et al. (2014). Certainly, the designated pointer years based on the Wrocław chronology corresponded to the local edaphic-climate conditions. Cedro and Nowak (2015) designated as many as 40 pointer years (13 positive and 27 negative) in a 111 year period, and among them only one, 1989, was consistent with our observations. In contrast, Stopa-Boryczka et al. (2007) determined a similar number of pointer years to our research. For example, pointer years occurred every 11 years in their Gdańsk chronology (1800-1982), and every 8 years for Torun (1781-1984). According to Stopa-Boryczka et al. (2007), pointer years for oaks 
were 1923 (negative year), 1960 (negative), 1981 (negative) and 1982 (positive). The same pointer years were observed in Wrocław chronology in the period 19142014. The pointer years determined in this paper were also noted by other researchers examining Quercus, e.g: two pointer years - 1966 and 1982 by Stajić et al. (2015), one positive year - 1982 by Bronisz et al. (2012), four positive years - 1923, 1953, 1960, and 1989 by Kędziora et al. (2012). The pointer years were also analyzed by (among others): Cedro (2007) in north-western Poland, Bronisz et al. (2012) in central Poland, and Lebourgeois et al. (2004) in northern France. Those researchers, similar to this paper, noted the following pointer years: 1917, 1981, and 1989. Also Romanian and Wrocław studies partly confirmed the formation of narrow treering widths in the years 1953 and 1981 (Nechita 2013).

\section{CONCLUSIONS \\ 5. ZAKLJUČAK}

In our study, in the period 1887-2014, tree-ring widths (TRWs) of pedunculate oak growing on the embankment of the Oder River in Wrocław, south western Poland, were generally (ca $51 \%$ ) 2 to $4 \mathrm{~mm}$ wide. Tree-rings wider than $>7 \mathrm{~mm}$ grew very seldom, comprising only $2.4 \%$ of all measured rings. The widest ring was $11.71 \mathrm{~mm}$ and the narrowest only $0.46 \mathrm{~mm}$.

The created site chronology covered 128 years from 1887 to 2014 . The average tree-ring width in 19152014 was $3.56 \mathrm{~mm}$; ranging from $2.41 \mathrm{~mm}$ to $5.44 \mathrm{~mm}$ in the early half of the study period (1915-1964), and from $2.10 \mathrm{~mm}$ to $4.45 \mathrm{~mm}$ in the later half (1965-2014). Higher variability, described by TRW standard deviation, was observed in the earlier half (1915-1964).

TRW was significantly positively influenced by air temperature in December of the previous year and in July of the current year, but only in the later half of the analyzed period. In the same period (1965-2014), precipitation in June of the previous year and in January and September of the current year also had a positive effect on TRW, while precipitation in July of the current year had a negative effect on TRW.

Ten pointer years were determined, in which narrow or wide tree-rings developed. Both in the group of positive pointer years $(1917,1966$ and 1982) as well negative years (1923, 1951, 1953, 1960, 1981, 1989 and 2009), we were unable to determine similar variation patterns of temperature and precipitation.

Research on the TRW series of pedunculate oaks on flood protection embankments should be continued. By analyzing numerous sites in the Oder valley, it will be possible to better understand the dendrometry of the created chronology and determine the effect of climate conditions on TRW.

\section{REFERENCES \\ 6. LITERATURA}

1. Annighöfer, P.; Beckschäfer, P.; Vor, T.; Ammer, C., 2015: Regeneration Patterns of European Oak Species (Quercus petraea (Matt.) Liebl., Quercus robur L.) in
Dependence of Environment and Neighborhood. Plos One, 10 (8): e0134935. https://doi.org/10.1371/journal. pone. 0134935 .

2. Baillie, M. G. L.; Pilcher, J. R., 1973: A simple crossdating program for tree-ring research, Tree-Ring Bulletin, 33: 7-14.

3. Bielak, K.; Dudzińska, M.; Pretzsch, H., 2015: Przyrost miąższości drzewostanów mieszanych i litych: wyniki $\mathrm{z}$ wybranych stałych powierzchni badawczych w Europie Srodkowej (Volume growth of mixed-species stands versus pure stands: results from selected long-term experimental plots in Central Europe). Sylwan, 159 (1): 22-35 (in Polish).

4. Bronisz, A.; Bijak, Sz.; Bronisz, K.; Zasada, M., 2012: Climate influence on radial increment of oak (Quercus sp.) in central Poland. Geochronometria, 39 (4): 276-284. https://doi.org/10.2478/s13386-012-0011-7.

5. Bryś, K.; Bryś, T., 2010: Reconstruction of the 217-year (1791 - 2007) Wrocław air temperature and precipitation series. Bulletin of Geography - physical geography series No 3/2010: 121-171. https://doi.org/10.2478/2332.

6. Cedro, A., 2007: Tree-ring chronologies of downy oak (Quercus pubescens), pedunculate oak (Q. robur) and sessile oak ( $Q$. petraea) in the Bielinek nature reserve: comparison of the climatic determinants of tree-ring width. Geochronometria, 26: 39-45. https://doi.org/10.2478/v10003-007-0005-2.

7. Cedro, A.; Nowak, G., 2015: Dendroclimatic investigations on Quercus rubra and Quercus robur in north-western Poland. Dendrobiology, 74: 123-133.

https://doi.org/10.12657/denbio.074.012

8. Čermák, J.; Simon, J.; Káňová, H.; Soňa, T., 2013: Absorptive root areas of large pedunculate oak trees differing in health status along a road in South Bohemia, Czech Republic. Urban For Urban Gree, 12: 238-245.

https://doi.org/10.1016/j.ufug.2013.02.003.

9. Čufar, K.; Šefc, B.; De Luis, M.; Morgos, A.; Grabner, M.; Merela, M.; Trajković, J. 2014: Tree-ring chronology of pedunculate oak (Quercus robur) and its potential for development of dendrochronological research in Croatia. Drvna industrija, 65 (2): 129-137.

https://doi.org/10.5552/drind.2014.1337

10. Danek, M.; Kłusek, M.; Krąpiec, M., 2007: The oak chronology (948-1314 AD) for the Żary area (SW Poland). Geochronometria, 26: 47-52, http://dx.doi.org/10.2478/v10003-007-0006-1.

11. Eaton, E.; Caudullo, G.; Oliveira, S.; De Rigo, D., 2016: Quercus robur and Quercus petraea in Europe: distribution, habitat, usage and threats. In: San-Miguel-Ayanz, J.; De Rigo, D.; Caudullo, G.; Houston, Durrant, T.; Mauri, A. (eds.): European Atlas of Forest Tree Species. Publication Office of European Union, Luxembourg, pp. e01c6dft.

12. Eckstein, D.; Bauch, J., 1969: Beitrag zur Rationalisierung eines dendrochronologischen Verfahrens und zur Analyse seiner Aussagesicherheit. Forstwiss, Centralbl., 88 (1): 230-250. https://doi.org/10.1007/BF02741777

13. Génova, M.; Máyer, P.; Ballesteros-Cánovas, J.; Rubiales, J. M.; Saz, M. A.; Díez-Herrero, A., 2015: Multidisciplinary study of flash floods in the Caldera de Taburiente National Park (Canary Islands, Spain). Catena 131: 22-34. https://doi.org/10.1016/j.catena.2015.03.007.

14. Gniot, M., 2007: Sukcesja dębu w drzewostanach sosnowych na siedliskach borowych (The oak succession in the pine stand in the coniferous forest habitats). Sylwan, 151 (5): 60-72 (in Polish).

15. González-González, B. D.; Vázquez-Ruiz, R. A.; GarcíaGonzález, I., 2015: Effects of climate on earlywood vessel formation of Quercus robur and Q. pyrenaica at a site 
in the northwestern Iberian Peninsula. Canadian J Forest Res, 45 (6): 698-709. https://doi.org/10.1139/cjfr-20140436.

16. Helama, S.; Sohar, K.; Läänelaid, A.; Mäkelä, H. M.; Raisio, J., 2016: Oak decline as illustrated through plantclimate interactions near the northern edge of species range. Bot Rev, 82: 1-23.

https://doi.org/10.1007/s12229-016-9160-3

17. Hollstein, E., 1980: Mitteleuropäische Eichenchronologie. Verl. Philipp von Zabern, Mainz am Rhein, Germany, $273 \mathrm{pp}$.

18. Holmes, R. L., 1983: Computer-assisted quality control in tree-ring dating and measurement. Tree-Ring Bulletin, 43: 69-78.

19. Hughes, M. K., 2002: Dendrochronology in climatology - the state of the art. Dendrochronologia, 20: 95-116. https://doi.org/10.1078/1125-7865-00011.

20. Jagodziński, A. M.; Ziółkowski, J.; Warnkowska, A.; Prais, H., 2016: Tree age effects on fine root biomass and morphology over chronosequences of Fagus sylvatica, Quercus robur and Alnus glutinosa stands. Plos One, 11 (2): e0148668.

https://doi.org/10.1371/journal.pone.0148668.

21. Jansons, Ā.; Matisons, R.; Puriña, L.; Neimane, U.; Jansons, J., 2015: Relationships between climatic variables and tree-ring width of European beech and European larch growing outside of their natural distribution area. Silva Fenn, 49 (1): 1-8. https://doi.org/10.14214/sf.1255

22. Kalbarczyk, R., 2010a: Unfavorable thermal conditions of air at the turn of the $20^{\text {th }}$ and $21^{\text {st }}$ centuries reducing crop productivity of pickling cucumber (Cucumis sativus L.) in Poland. Span J Agric Res, 8 (4): 1163-1173.

https://doi.org/10.5424/sjar/2010084-1406

23. Kalbarczyk, R., 2010b: Spatial and temporal variability of the occurrence of ground frost in Poland and its effect on growth, development and yield of pickling cucumber (Cucumis sativus L.), 1966-2005. Acta Sci Pol-Hortoru, 9 (3): 3-26.

24. Kalbarczyk, R.; Ziemiańska, M.; Machowska, A., 2016: Effect of climatic conditions on tree-ring widths in black locust (Robinia pseudoacacia L.) in the city of Wrocław. Drvna Industrija, 67 (1): 33-41. https://doi.org/10.5552/drind.2016.1512

25. Kalbarczyk, K.; Ziemiańska, M., 2016: The effect of air temperature, precipitation and humidity on ring widths in the black locust (Robinia pseudoacacia L.) growing in urban conditions. Wood Res-Slovakia, 61 (3): 351-362.

26. Kędziora, W.; Tomusiak, R., 2012: Dendrochronologiczna analiza przyrostów radialnych dębu szypułkowego (Quercus robur L.) z terenu Mazurskiego Parku Krajobrazowego. Zeszyt, 1 (30): 29-36. SiM CEPL Rogów (in Polish).

27. Khasanov, B. F., 2013: Severe winter rings of oak trees (Quercus robur L.) from Central European Russia. Int J Biometeorol, 57 (6): 835-843. https://doi.org/10.1007/s00484-012-0611-1

28. Kraler, A.; Beikircher, W.; Zingerle, P., 2012: Suitability of drill resistance measurements for dendrochronological determination, World Conference on Timber Engineering, Auckland, New Zealand.

29. Krąpiec, M.; Szychowska-Krąpiec, E., 2004: Standardy dendrochronologiczne sosny zwyczajnej (Pinus sylvestris L.) i dębu szypułkowego (Quercus robur L.) z północno-wschodniej Polski. (Dendrochronological standards of Scots pine (Pinus sylvestris L.) and English oak (Quercus robur L.) from north-eastern Poland). Sylwan, 7: 11-19 (in Polish).
30. Krutul, D.; Zielenkiewicz, T.; Zawadzki, J., 2014: Influence of urban environment originated heavy metal pollution on extractives and mineral substances content in bark and wood of oak (Quercus robur L.). Wood ResSlovakia, 59 (1): 177-190.

31. Krzyżaniak, M.; Świerk, D.; Urbański, P.; Walerzak, M., 2013: Evaluation of the effect of environmental variables on health condition of Quercus robur L. in park. Ecol Chem Eng S, 20 (4): 689-700.

https://doi.org/10.2478/eces-2013-0047

32. Lebourgeois, F.; Cousseau, G.; Yves Ducos, Y., 2004: Climate-tree-growth relationships of Quercus petraea Mill. stand in the Forest of Bercé ("Futaie des Clos", Sarthe, France). Ann For Sci, Springer Verlag/EDP Sciences, 61 (4): 361-372.

https://doi.org/10.1051/forest:2004029

33. Lorenc, H. (ed.), 2005: Atlas klimatu Polski (Climatic Atlas of Poland). Instytut Meteorologii i Gospodarki Wodnej, Warszawa (in Polish).

34. Majewski, G.; Przewoźniczuk, W.; Kleniewska, M., 2014: The effect of urban conurbation on the modification of human temperature perception, as illustrated by the example of Warsaw (Poland). Theor Appl Climatol, 116: $147-154$. https://doi.org/10.1007/s00704-013-0939-4

35. Mäkinen, H.; Vanninen, P., 1999: Effect of sample selection on the environmental signal derived from tree-ring series. Forest Ecol Manag, 113: 83-89. https://doi.org/10.1016/S0378-1127(98)00416-2

36. Matisons, R.; Elferts, D.; Brūmelis, G., 2013: Pointer years in tree-ring width and earlywood-vessel area time series of Quercus robur - Relation with climate factors near its northern distribution limit. Dendrochronologia, 31: 129-139.

https://doi.org/10.1016/j.dendro.2012.10.001

37. Nechita, C., 2013: The influence of early wood and late wood to emergence of pointer years in oak trees. Journal of Horticulture, Forestry and Biotechnology, 17 (2): 41-47.

38. Okoński, B.; Koprowski, M.; Danielewicz, W.; Miler, A.T.; Kasztelan, A., 2014: Wykorzystanie lat wskaźnikowych do oceny wpływu reżimu rzecznego na warunki wzrostu drzew w dolinie Warty. SiM CEPL w Rogowie 16, 40 (3): 156-164.

39. Paluch, R., 2013: Height growth rate of pedunculate oak (Quercus robur L.) in lower layer of Scots pine stand. Sylwan, 157 (12): 909-916.

40. Pritzkow, C.; Ważny, T.; Heußner, K. U.; Słowiński, M.; Bieber, A.; Dorado, Liñán, I.; Helle, G.; Heinrich, I., 2016: Minimum winter temperature reconstruction from average earlywood vessel area of European oak (Quercus robur) in N-Poland. Palaeogeogr Palaeocl, 449: 520-530. https://doi.org/10.1016/j.palaeo.2016.02.046

41. Rinn, F., 2012: TSAP-Win User Reference. Heidelberg, Germany.

42. Rybníček, M.; Čermák, P.; Žid, T.; Kolář, T., 2010: Radial growth and health condition of Norway spruce (Picea abies (L.) Karst.) stands in relation to climate (Silesian Beskids, Czech Republic). Geochronometria, 36: 9-16. https://doi.org/10.2478/v10003-010-0017-1

43. Rybníček, M.; Čermák, P.; Prokop, O.; Žid, T.; Trnka, M.; Koláŕ, T., 2016: Oak (Quercus spp.) response to climate differs more among sites than among species in central Czech Republic. Dendrobiology, 75: 55-65. DOI 10.12657/denbio.075.006.

44. Rasheed-Depardieu, C.; Parelle, J.; Tatin-Froux, F.; Parent, F.; Capelli, N., 2015: Short-term response to waterlogging in Quercus petraea and Quercus robur: A study 
of the root hydraulic responses and the transcriptional pattern of aquaporins. Plant Physiol Bioch, 97: 323-330. https://doi.org/10.1016/j.plaphy.2015.10.016

45. Schweingruber, F. H., 1989: Tree rings. Basics and applications of dendrochronology. Kluwer Academic Publishers, pp. 1-276.

46. Seneta, W.; Dolatowski, J., 2012: Dendrologia (Dendrology). Wydawnictwo Naukowe PWN, Warszawa (in Polish).

47. Sohar, K.; Vitas, A.; Läänelaid, A., 2012: Sapwood estimates of pedunculate oak (Quercus robur L.) in eastern Baltic. Dendrochronologia, 30: 49-56. https://doi.org/10.1016/j.dendro.2011.08.001

48. Sohar, K.; Läänelaid, A.; Eckstein, D.; Helama, S.; Jaagus, J., 2014: Dendroclimatic signals of pedunculate oak (Quercus robur L.) in Estonia. Eur J For Res., 133: 535549. https://doi.org/10.1007/s10342-014-0783-9

49. Stajić, B.; Vučković, M.; Janjatović, Ž., 2015: Preliminary Dendroclimatological Analysis of Sessile Oak (Quercus petraea (Matt.) Liebl.) in "Fruška Gora" National Park, Serbia. Balt For., 21 (1): 83-95.

50. Stojanović, D. B.; Levanič, T.; Matović, B.; Orlović, S., 2015: Growth decrease and mortality of oak floodplain forests as a response to change of water regime and climate. Eur J For Res., 134: 555-567. https://doi.org/10.1007/s10342-015-0871-5

51. Stopa-Boryczka, M.; Boryczka, J.; Bijak, Sz.; Cebulski, R.; Błażek, E.; Skrzypczuk, J., 2007: Atlas of correlations between meteorological and geographical parameters in Poland. Warszawa. Wydawnictwa Uniwersytetu Warszawskiego (in Polish).

52. Szymanowski, M.; Kryza, M., 2012: Local regression models for spatial interpolation of urban heat island - an example from Wrocław, SW Poland. Theor Appl Climatol., 108: 53-71. https://doi.org/10.1007/s00704-011-0517-6

53. Tulik, M., 2014: The anatomical traits of trunk wood and their relevance to oak (Quercus robur L.) vitality. Eur J For Res., 133: 845-855. https://doi.org/10.1007/s10342-014-0801-y
54. Tulik, M.; Bijak, Sz., 2016: Are climatic factors responsible for the process of oak decline in Poland? Dendrochronologia, 38: 18-25. https://doi.org/10.1016/j.dendro.2016.02.006

55. Ważny, T., 1990: Aufbau und Anwendung der Dendrochronologie für Eichenholz in Polen. Dissertation Universität Hamburg, pp. 1-213.

56. Wigley, T. M.; Briffa, K. R.; Jones, P. D., 1984: On the average value of correlated time series with applications in dendroclimatology and hydrometeorology. Journal of Climate and Applied Meteorology, 23 (2): 201-213. https://doi.org/10.1175/1520-0450(1984)023<0201:OTAVOC $>2.0 . \mathrm{CO} ; 2$

57. Zielski, A.; Krąpiec, M., 2004: Dendrochronologia (Dendrochonology). Warszawa, Wydawnictwo Naukowe PWN (in Polish).

58. Ziemiańska, M.; Suchocka, M., 2013: The planning and principles of tree protection in the investment process, in the book Sustainable Development Applications Journal 4/2013 (Nature in the city - solutions), Edition: 1, Chapter: 1, Publisher The Sendzimir Foundation, Kraków, pp. $11-25$.

\section{Corresponding address:}

\section{MONIKA ZIEMIAŃSKA}

Wrocław University of Environmental and Life Sciences

Faculty of Environmental Engineering and Geodesy Institute of Landscape Architecture

Grunwaldzka Street 55

50-357 Wrocław, POLAND

e-mail: monika.ziemianska@upwr.edu.pl 